Kruhlov, V.V., and Tereshchenko, D.A.

Kharkiv National University of Construction and Architecture,

40, Sumska St., Kharkiv, 61002, Ukraine,

+380 57700 0250, office@kstuca.kharkov.ua

\title{
PUBLIC-PRIVATE PARTNERSHIP AS TOOL FOR DEVELOPING REGIONAL LABOR POTENTIAL
}

\begin{abstract}
Introduction. The modern direction of infrastructure development is the attraction of the private owner by the state under public-private partnership (PPP) agreements.

Problem Statement. Analysis of the possibilities of PPP for the development of labor potential in the modern labor market, taking into account the peculiarities of interaction between public and private capital and on the basis of their economic and social objectives, is an important issue of our time.

Purpose. Justification of the objectives and directions of public-private partnership as a tool for the development of labor potential, taking into account the main objectives of the implementation of infrastructure projects.

Materials and Methods. Method of theoretical generalization and systematization (to determine the specific features of forming PPP and labor potential in the modern labor market); monographs (a review of scientific ideas about the problem of developing PPP, and the sphere of education); statistical method (to present the key figures that characterize PPP and labor potential); the analytical method (to identify factors that influence implementation of PPP projects as a tool for labor potential development).
\end{abstract}

Results. The implementation of PPP projects has been found to stimulate the labor market and to enhance labor capacity. In case of successful implementation of PPP projects, social problems will be solved due to improved quality of services in the field of education, healthcare, culture, etc. Implementation of the innovation projects of public-private partnership in education and science shapes actually the prerequisites for an increase in figures that characterize labor potential as a whole, and involves staff in specific projects where the key approach is satisfaction of the need for highly qualified specialists.

Conclusions. The state policies of PPP development, innovational development of the economy and strengthening labor potential should be aimed at establishing a legislative basis for the institutional environment; introduction of effective economic mechanisms; establishing up-to-date standards which apply to the key development paths of knowledge-based economy.

Keywords: labor potential, public-private partnership, education and innovations.

The present-day economies in the overwhelming majority of the world countries, irrespective of their level of development, require financial and resource support. Solution to social problems is connected with implementation of infrastructure projects in the spheres of energy saving, transport networks, healthcare, education, tou-

(C) KRUHLOV, V.V., and TERESHCHENKO, D.A., 2019 rism, management of household wastes, introduction of alternative energy sources. The evolution of public administration theory over time creates modern models of interaction of different forms of ownership in order to address the pressing needs of the country. Involvement of private business in large-scale public projects which until recently were eminently the focus area of the state is a difficult task, therefore it is implemen- 
ted through effective state regulation mechanisms and the necessary institutions.

In the recent decades, public-private interaction has been introduced in the form of publicprivate partnership (PPP). Solution of numerous current problems has also been done in the PPP form. The problem range in question was elucidated in multiple theoretical and empirical studies. While at first private capital was mostly involved in fulfillment of tasks of transport infrastructure development and municipal services, the last decade provides examples of introducing public-private partnership in the 'green economy' projects, Smart City [1], e-government and information-communication technologies [2]. These trends can testify to an important role of PPP in addressing a broader agenda of today's society. A highly technological area of the public-private partnership domain suggests an idea of its prominent role in developing the knowledge-based economy, and consequently, in shaping human capital and development of labor capacity.

Infrastructure-building projects are one of the key parameters of the economic growth, being able to a large extent promote living standards improvement [3]. The developing countries need to have annually USD 0.9 to 1.1 trillion [4] in order to achieve their developmental goals.

The current state of social development requires high rates of the production and services sectors; thus, a demand for highly qualified experts, capable of innovational thinking and decision-making under uncertainty and risks, is growing. The state is responsible for fulfillment of the tasks of forming institutional, legislative, and information approaches to enhancement of labor potential and efficiency of its employment. It is deemed essential to analyze the possibilities of PPP for developing labor potential in the modern labor market, taking into consideration the specificity of interaction of public and private capital with civil society institutions, based on their economic and social goals and the need for introduction of innovative approaches in the educational and scientific spheres.
The subject of public-private partnership has been researched in full in scientific literature. Separate issues of PPP application were explored by L. Dupont [1], G. Hodge [5], R. Narasimhan [2], T. Nisar [6], M. Trebilcock [3] and other scholars. Various aspects of labor potential formation were considered in the works by I. Filippova [7], A. Milev [8], M. Popova [9], E. Semenchin [9], Y. Vorokhobina [9], I. Zaytseva [9], and other researchers.

In view of a wide range of PPP projects in the world, creation of high-technology infrastructure, and social orientation of project results, a need arises to explore public-private partnership as a tool for regional labor potential development.

The paper objective is substantiation of the tasks and areas of public-private partnership as a tool for regional labor potential development with account of the main goals of infrastructure projects implementation.

The mechanisms of public-private partnership provide an opportunity for realization of projects that would be impossible to realize, if private or public sector worked alone [10]. PPP is an innovative approach to relations between the public and private sectors which cooperate to develop the infrastructure and deliver public services, sharing risks, losses and advantages [11].

Public-private partnership in the context of the innovation policy is a sort of coordination of the interests of the public and private sectors, which allow implementing innovation projects within the framework of scientific non-commercial partnerships, in production partnerships with research and educational establishments, and in cluster formations (innovation cities and parks), resulting in improved provision of social benefits [12].

Some definitions of PPP emphasize public and private partners' broader opportunities obtained due to involvement of private capital in infrastructure projects [5], and partners' making profits within the contract [6].

The private sector receives through PPP projects an opportunity to use new resources, attract additional consumers, reduce risks, and gain re- 
putation benefits [13]. The public sector strives: to go from a budget deficit to surplus, plug holes in public services demand, provide an alternative to ineffective public services, improve performance, employ innovation technological developments and management capabilities, offer an opportunity for private owners to participate in creation of social services [14, 15].

The current global state of public-private partnership is characterized by a multitude of projects and a large general scope of investments. Dynamics of project numbers in the developing countries, and amounts of investment over a period of 2008-2017 [16] are shown in Figure. The proposed sampling takes into account the information about infrastructure projects of 132 countries with low and middle incomes.

The governments of the developing countries implement projects with the help of PPP mechanisms, thus increasing the number and improving quality of delivered infrastructure services. Due to public-private partnership mechanisms, construction is carried out in transport (highways, railways, airports and sea ports); in electrical energy industry (energy generation and distribution); in telecommunications and water distribution grids (collection, treatment, distribution) [17].

According to the European Investment Bank [18], over the period of 2006-2017, the majority

\section{Sectoral Structure of PPP Projects in Europe, in 2006-2017}

\begin{tabular}{|l|c|c|}
\hline \multicolumn{1}{|c|}{ Sector } & $\begin{array}{c}\text { Project } \\
\text { number }\end{array}$ & $\begin{array}{c}\text { Total amount } \\
\text { of investment, } \\
\text { EUR billion }\end{array}$ \\
\hline Education & 281 & 24.245 \\
Transport & 229 & 114.567 \\
Healthcare & 204 & 32.677 \\
Public order and safety & 77 & 6.898 \\
Environment & 78 & 13.324 \\
Housing and community & 61 & 5.678 \\
services & 56 & 3.597 \\
Recreation and culture & 29 & 3.328 \\
General public services & & \\
\hline
\end{tabular}

Source: created by the authors on the basis of [18].

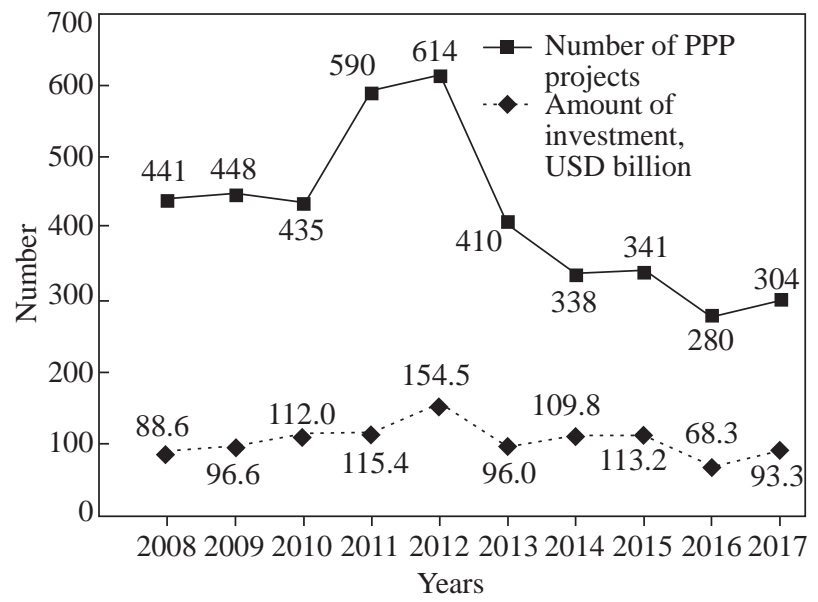

The number of PPP projects and amount of investment Source: created by the authors on the basis of [16].

of projects were implemented in the social sphere (Table).

According to the data of the Ukrainian central and local executive authorities, by July 1, 2018, 192 PPP partnerships had been signed, 66 projects thereof being at the implementation stage. The projects are realized in the following economic spheres: collection, purification and distribution of water (31 agreements, $47.0 \%$ of the total); production, transportation and supply of heat (8 agreements, $12.1 \%$ of the total); waste processing ( 7 agreements, $10.6 \%$ of the total); construction and/or maintenance of motorways, roads, railways, airport runways, bridges, overhead roads, tunnels and metro systems, sea and river ports, and their infrastructure ( 7 agreements, $10.6 \%$ of the total); real estate management ( 4 agreements, $6.1 \%$ of the total); production, distribution, and supply of electric energy (3 agreements, $4.5 \%$ of the total); other spheres (6 agreements, $9.1 \%$ of the total) [19].

As we can see, in Ukraine only 34 percent of projects of the total number of PPP agreements signed are at the implementation stage. The reasons for this situation are the underdeveloped Ukrainian PPP mechanisms, a large number of risks in project implementation, problems with provision of state guarantees, and financial disability of a part of private partners. 
The infrastructure facilities which form life quality and human capital development affect directly labor capacity as well. Human capital as an active part of labor potential is regarded as a source of competitive advantage [20]. A broader understanding of human capital determines a larger number of investment areas: education, healthcare, science, work incentives, migration processes.

Investment resources involved by private partners in infrastructure projects stimulate labor market development and raise the efficiency of labor potential use. Up-to-date equipment, hi-tech processes, introduction of innovative management models, which will be used in public-private partnership, are going to bring about a qualitative change in the system of staff work organization. The results are supposed to be positive changes in work remuneration, improvement of safety and health protection, strengthened social security, upgrading of staff qualifications.

The innovation aspect of PPP projects should be mentioned too: obviously it is necessary to invite highly skilled specialists to implement innovative decisions. This task presupposes training of specialists in the appropriate fields by way of continuous target-oriented instruction, retraining, internships abroad, in-service training, search for and recruitment of staff having required qualification, training of public authority specialists to fulfill government functions in the course of PPP projects realization. When getting entrepreneurs involved in PPP projects, it is requisite to develop the labor potential of the partnership participants, in the first place, by providing an economic entity with the appropriate management staff and experts, and forming an effective mechanism for upgrading staff competency.

Regional labor potential is often considered within the scope of quantitative and qualitative assessment of work force: general capacity of the population for generating a quantitative value of wealth; amount of work done in terms of man hours; human resource factors, related to such parameters as health condition, education etc. Labor potential is determined as a capacity of an individual, group, or society (based on personal growth of an individual) for creative purposeful transformation of the environment, aimed at creation of qualitatively new benefits which would satisfy social needs. The size of development determines the measure of social progress and serves an indicator of social labor potential dynamics [7].

The socio-economic policy ensures formation of the conditions for a full actualization of staff labor potential and promotes the development of professional skills, which activates human factor of labor productivity [8]. With the aid of economic, social, and mathematical methods, evaluation of the impact of labor potential on the economic development is performed, which helps describe a variety of labor potential characteristics: demographic, organizational, sociological, psychological etc. [21]. Changes in labor potential happen constantly, influenced by a number of socio-economic processes: hiring the formerly unemployed; migration movements and their costs; changing the number of people under and over the active working age; deceased people of employable age; pensioners; people of the active working age who study full-time or do military service [9].

Enhancement of labor potential can be achieved due to an increase in work force percentage in the total number of working-age population (participation coefficient), e.g. by engaging pension-age workers; reducing unemployment (employment rate); extension of an average number of working hours per worker through introduction of extra working time [22]. To our mind, this approach to strengthening of labor potential should take into account social factors: life expectancy, average expected lifespan, unemployment rate. Also, it is essential to ensure financing of the above-mentioned measures from the state budget.

In case of successful implementation of PPP projects involving the state, business, and civil society actors, ultimately, important social and humanitarian problems of the society are solved; thus, a direct impact on human development is 
achieved and the living standards are improved through the spheres of education, healthcare, culture, environmental protection, etc.

Analyzing the areas of implementing PPP projects of social infrastructure, it should be emphasized that the majority of them are directed to create new jobs (including in the public sector, consumer services, trade, insurance business, and banking); to improve job opportunities in hi-tech spheres; to upgrade the healthcare system; to increase the number of specializations and to imp rove education services quality; to facilitate migration processes; to enhance security for the society and individuals; and to increase the indices that determine the quality of life.

Public-private partnership projects in the socio-humanitarian sphere strengthen labor potential due to investments in education, retraining on-the-job, healthcare and other measures aimed at development of human traits, competences, and motivation. Thus, implementation of public-private partnership projects actually forms prerequisites for an increase in figures, determining labor potential in general, and involves staff directly in specific projects where major approach is the need for specialists with a high labor potential.

The modern concepts of life quality measurability, sustainable development consider the necessity for using indices which determine subjective well-being, human capacity, and fair distribution of resources. Objective characteristics that form life quality are regarded to be health, education, personal activity, environmental conditions [23].

While assessing the labor potential of a region and a country, it is expedient to explore the relevant indices which take account of the quantitative ratings of labor potential (the number of able-bodied citizens, employment rate, migration factors); educational potential (education level, level of upgrading qualifications); factors related to the population's health (standard of health, healthcare level, average expected lifespan); environmental parameters. As additional alternative indices, the prosperity index and global human capital index can be used.
PPP projects can include practically all the aspects of education: policy-making, drawing plans, evaluation and implementation, management, funding of institutions, academic aspects, specialized education programs, additional services, dormitories etc. [24]. Advantages of the public sector in PPP projects implementation in the sphere of education are as follows: creation of an innovative model and enhancement of competitive advantages of the state that takes into account the global vectors of the knowledge-based economy; formation of legislative framework aiming to increase labor potential by implementing PPP projects; further development of the management system in the field of innovations; training specialists in the sphere of management. In the private sector: participation in forming and conducting research, scientific, educational activities; setting educational standards that would meet the challenges of the labor market; involvement of scientific staff in carrying out business projects; creation of production and technological infrastructure. In the education sphere: increased funding of educational establishments and scientific research; designing innovative models of teaching and research; development of integration between educational establishments and employers [25].

Public-private partnership in the educational sphere consists in an integrating interaction of the state, businesses, and educational institutions at different stages of the education services life cycle, which forms potential opportunities of improving education service quality, raising the effectiveness of service delivery mechanisms and models; implementation of socially important projects in the sphere of educational establishments infrastructure. Strategic partnership of educational establishments, research organizations, and enterprises is expressed in long-term agreements and programs of cooperation in research and educational spheres; staff, resource, and financial support for joint activities; target-oriented training of staff for enterprises; conducting joint scientific, research and development activity; creation 
of joint structures of educational, scientific, and innovational profiles [26].

A qualitatively distinctive feature of the pattern of interaction between the state, businesses, and educational institutions is that it should take into account the impact of PPP on the society due to social orientation of educational services, and fulfillment of state functions and realization of the state educational policy. The forms of partnership cooperation are development of technoparks, resource centers, and centers for transfer of technologies, which presupposes public-private partnership in the field of scientific studies, research and design efforts for creation of innovative products, upgrading technological processes, etc. [27]. Priority areas of innovation cluster as a form of PPP are innovation-oriented infrastructure projects, and projects in the spheres of science, technology and education [28].

Similarly to approaches in the field of education, the PPP projects in healthcare, environmental protection, and other social spheres can be developed, which will have a direct impact on labor potential development. It is possible to point out factors that will promote the development of PPP as a tool of labor potential development, and namely: institutional environment, economic mechanisms, social factors, demographic factors, environmental determinants.

The institutional environment presupposes that the state should create the appropriate legal norms and institutions which are to intensify the development of public-private partnership in the spheres of education, healthcare, communal services, environmental protection. Economic mechanisms should raise the efficiency of PPP project realization, provide financial system transparency, reduce tax burden for investors, and protect investors' money, enhancing reliability of PPP projects.

Realization of PPP projects should guarantee better social standards for staff, modern labor conditions, labor protection measures, professional programs of staff training and retraining, possibilities of involving qualified staff from other regions, setting up ecologically clean production and service delivery on the basis of using ecologically clean energy sources. Public authorities, local government bodies can find the necessary impetus for developing labor potential of a region by activating public-private partnership mechanisms in full extent both at the local communities' level and for implementation of large-scale infrastructure projects.

As part of the study, the basic orientation of PPP projects was identified. It has been found that a large number of projects, in which the state, businesses, and civil society actors are engaged, are implemented along the lines of building social infrastructure, which allows the state to provide socially important services. The standards and quality of services provided in healthcare, education, housing and municipal services gradually form the quality of life. The categories of living standards, life quality, security, and motivation affect directly the formation of human capital which is an active part of labor potential. Active actions on behalf of the state aimed to form the policy of public-private partnership, implement PPP projects in the sphere of education and science will be able to enhance the labor potential of Ukraine. Basing on some individual indices that show the level of education, healthcare, employment, a quantitative index of regional labor potential can be estimated. Public resources put to work in social functions are insufficient to develop labor potential at an adequate quality level. Possibilities of public-private partnership allow using private capital for implementation of various PPP projects in the field of education infrastructure. A special mentioning should be made of PPP projects in the sphere of education, where there is a direct possibility of forming approaches to education areas, issues of retraining specialists, scientific developments which also affect directly the size of labor potential. The tools for PPP development in the fields of education and science can be creation and growth of technological parks, resource centers, innovation clusters. The tasks of the state as to 
developing PPP and strengthening labor potential should be as follows: fulfillment of the functions of an equal partner in infrastructure projects; legislative formation of institutional environment for PPP; introduction of effective economic mechanisms; protection of investors' interests; involvement of civil society's representatives; minimization of bureaucratic proce- dures; creation of effective forms of interacting with private capital in various spheres of activity; making of labor potential development policy; elaboration of methodological approaches to identification of risks and project efficiency; establishing up-to-date standards which apply to the key development paths of knowledge-based economy.

\section{REFERENCES}

1. Dupont, L., Morel, L., \& Guidat, C. (2015). Innovative public-private partnership to support Smart City: the case of "Chaire REVES". Journal of Strategy and Management, 8(3), 245-265.

2. Narasimhan, R., \& Aundhe, M. D. (2014). Explanation of Public Private Partnership (PPP) Outcomes in E-Government - Social Capital Perspective. System Sciences (HICSS). 47 th Hawaii International Conference. January 6-9, 2014, Waikoloa, 2189-2199.

3. Trebilcock, M., \& Rosenstock, M. (2015). Infrastructure public-private partnerships in the developing world: Lessons from recent experience. The Journal of Development Studies, 51(4), 335-354.

4. Fay, M., \& Yepes, T. (2003). Investing in Infrastructure: What is Needed from 2000 to 2010? Policy Research Working Paper; № 3102. The World Bank. URL: https://openknowledge.worldbank.org/handle/10986/18147 (Last accessed: 12.12.2018).

5. Hodge, G. A., \& Greve, C. (2007). Public-private partnerships: an international performance review. Public administration review, $67(3), 545-558$.

6. Nisar, T. M. (2007). Value for money drivers in public private partnership schemes. International Journal of Public Sector Management, 20(2), 147-156.

7. Filippova, I. H. (2012). Institutional components of public labor potential. MPRA Paper 51422, URL: https://mpra. ub.uni-muenchen.de/51422/1/MPRA_paper_51422.pdf (Last accessed: 12.12.2018).

8. Milev, A. Y. (2017). Management of the development of the region based on mobilization of labor potential. ISJ Theoretical \& Applied Science, 10(54), 88-91.

9. Zaytseva, I. V., Semenchin, E. A., Vorokhobina, Y. V., \& Popova, M. V. (2014). Optimal control of labour potential of the region. Life Science Journal, 11(11s), 674-678.

10. Vinogradov, D., Shadrina, E., \& Kokareva, L. (2014). Public procurement mechanisms for public-private partnerships. Journal of Public Procurement, 14(4), 538-566.

11. Koppenjan, J. F. M. (2005). The formation of public-private partnerships: Lessons from nine transport infrastructure projects in the Netherlands. Public Administration, 83(1), 135-157.

12. Fedchenko, M. A., \& Kosach, I. A. (2013). The public-private partnership in the sphere of innovations: ukrainian and abroad experience. Visnyk of Chernihiv State Technological University, series «Economic sciences», 2, 365-371 [in Ukrainian].

13. Shambaugh, G. E., \& Matthew, R. A. Sustaining Public-Private Partnerships. (2015). International Studies Association Annual Conference New Orleans. Febuary 20, 2015, New Orlean. URL: https://ssrn.com/abstract=2658197 (Last accessed: 12.12.2018).

14. Chowdhury, A. N., Chen, P. H., \& Tiong, R. L. K. (2011). Analysing the structure of public-private partnership projects using network theory. Construction Management and Economics, 29(3), 247-260.

15. Hwang, B.-G., Zhao, X., \& Gay, M. J. S. (2013). Public private partnership projects in Singapore: Factors, critical risks and preferred risk allocation from the perspective of contractors. International Journal of Project Management, 31(3), 424-433.

16. PPI Project Database. World Bank. URL: http://ppi.worldbank.org (Last accessed: 12.12.2018).

17. Sharma, C. (2012). Determinants of PPP in infrastructure in developing economies. Transforming Government: People, Process and Policy, 6(2), 149-166.

18. EPEC Data Portal. European Investment Bank. URL: http://data.eib.org/epec (Last accessed: 12.12.2018).

19. Monitoring of PPP implementation in Ukraine. URL: http://www.me.gov.ua/Documents/Detail?lang=uk-UA\&id= 62a9b6fb-27ff-462a-b351-eeeadfb26b6f\&title=StanZdiisnenniaDppVUkraini (Last accessed: 12.12.2018). 
20. Bogomolova, I. S., Grinenko, S. V., \& Zadorozhnyaya, E. K. (2015). Development of the human capital taking into account a gender factor in Russia. Mediterranean Journal of Social Sciences, 6(3 S4), 237-244.

21. Zaitseva, I., \& Popova, M. (2013). Technique to study the employment potential of the region: economicmathematical aspect. World Applied Sciences Journal, 22(1), 22-25.

22. Hamm, I., Seitz, H., \& Werding, M. (2008). Demographic change in Germany. Berlin: Springer.

23. Stiglitz, J. E., Sen, A., \& Fitoussi, J. P. (2010). Mismeasuring our lives: Why GDP doesn't add up. The New Press.

24. Tilak, J. B. G. (2016). Public private partnership in education. Discussion Paper Series № 3/2016. URL: http:// www.headfoundation.org/papers/2016_3)_Public_Private_Partnership_in_Education.pdf (Last accessed: 12.12.2018).

25. Upabekov, A. E., \& Nechayeva, Y. L. (2017). Public-private partnershipas a tool for the development of human capital in the republic of Kazakhstan. Man in India, 97(14), 465-480.

26. Yavorska, M. (2017). The public and private partnership as an innovative approach of the administrative management in the educational system. Youth $\mathcal{E}$ market, 6, 161-164 [in Ukrainian].

27. Moskvichova, O. (2016). Public-private partnership in the field of vocational and higher education. Economics and organization of management, 2(22), 291-299 [in Ukrainian].

28. Nifatova, O. M., \& Shkoda, M. S. (2017). Enhancing the innovative development policy through building innovation clusters in the framework of public-private partnership. Bulletin of Kyiv National University of Technologies and Design, Series: Economics, 6, 110-120 [in Ukrainian].

Received 01.11.18

Revised 08.01.19

Accepted 29.01.19

\section{В.В. Круглов, Д.А. Терещенко}

\section{Харківський національний університет будівництва та архітектури, вул. Сумська, 40, Харків, 61002, Україна, \\ +380 57700 0250, office @kstuca.kharkov.ua \\ ДЕРЖАВНО-ПРИВАТНЕ ПАРТНЕРСТВО \\ ЯК ІНСТРУМЕНТ РОЗВИТКУ ТРУДОВОГО ПОТЕНЦІАЛУ}

Вступ. Сучасним напрямом реалізації розбудови інфраструктури є залучення державою приватного власника в межах договорів про державно-приватне партнерство (ДПП).

Проблематика. Аналіз можливостей ДПП для розвитку трудового потенціалу на сучасному ринку праці, враховуючи особливості взаємодії державного та приватного капіталу та виходячи з їх економічних і соціальних цілей, $€$ важливим питанням сьогодення.

Мета. Обгрунтування завдань та напрямів державно-приватного партнерства як інструменту розвитку трудового потенціалу, враховуючи основні цілі реалізації інфраструктурних проектів.

Матеріали й методи. Методи теоретичного узагальнення й систематизації (для визначення особливостей формування ДПП і трудового потенціалу на сучасному ринку праці), монографічний (огляд наукових поглядів на проблеми розвитку ДПП), статистичний метод (для відображення показників, що характеризують ДПП і трудовий потенціал), аналітичний метод (для визначення факторів, що впливають на реалізацію проектів ДПП як інструменту розвитку трудового потенціалу).

Результати. Встановлено, що реалізація проектів ДПП стимулює розвиток ринку праці та підвищує трудовий потенціал. У разі успішної реалізації проектів ДПП вирішуються соціальні проблеми за рахунок зростання якості послуг у галузі освіти, медицини, культури та ін. Реалізація інноваційних проектів державно-приватного партнерства у галузі освіти та науки безпосередньо формує передумови для зростання показників, що визначають трудовий потенціал в цілому та безпосередньо залучає персонал у конкретні проекти, де ключовим підходом є необхідність у висококваліфікованих фахівцях.

Висновки. Державна політика розвитку ДПП, інноваційного розвитку економіки та підвищення трудового потенціалу повинна спрямовуватися на законодавче формування інституційного середовища, впровадження ефективних економічних механізмів, формування сучасних стандартів, які відповідають основним напрямам розвитку економіки знань.

Ключові слова: трудовий потенціал, державно-приватне партнерство, освіта, інновації. 


\section{В.В. Круглов, Д.А. Терещенко \\ Харьковский национальный университет строительства и архитектуры, ул. Сумская, 40, Харьков, 61002, Украина, +380 57700 0250, office @kstuca.kharkov.ua \\ ГОСУДАРСТВЕННО-ЧАСТНОЕ ПАРТНЕРСТВО КАК ИНСТРУМЕНТ РАЗВИТИЯ ТРУДОВОГО ПОТЕНЦИАЛА}

Введение. Современным направлением реализации инфраструктурного развития является привлечение государством частного собственника в рамках договоров о государственно-частном партнерстве (ГЧП).

Проблематика. Анализ возможностей ГЧП для развития трудового потенциала на современном рынке труда, учитывая особенности взаимодействия государственного и частного капитала и исходя из их экономических и социальных целей, является важным вопросом современности.

Цель. Обоснование задач и направлений государственно-частного партнерства как инструмента развития трудового потенциала, учитывая основные цели реализации инфраструктурных проектов.

Материалы и методы. Методы теоретического обобщения и систематизации (для определения особенностей формирования ГЧП и трудового потенциала на современном рынке труда); монографический (обзор научных взглядов на проблемы развития ГЧП); статистический метод (для отображения показателей, характеризующих ГЧП и трудовой потенциал); аналитический метод (для определения факторов, влияющих на реализацию проектов ГЧП как инструмента развития трудового потенциала).

Результаты. Установлено, что реализация проектов ГЧП стимулирует развитие рынка труда и повышает трудовой потенциал. В случае успешной реализации проектов ГЧП решаются социальные проблемы за счет роста качества услуг в сфере образования, медицины, культуры и др. Реализация инновационных проектов государственночастного партнерства в сфере образования и науки непосредственно формирует предпосылки для роста показателей, определяющих трудовой потенциал в целом и непосредственно привлекает персонал в конкретные проекты, где ключевым подходом является необходимость в высококвалифицированных специалистах.

Выводы. Государственная политика развития ГЧП, инновационного развития экономики и повышения трудового потенциала должна направляться на законодательное формирование институциональной среды, внедрение эффективных экономических механизмов, формирование современных стандартов, соответствующих основным направлениям развития экономики знаний.

Ключевые слова: трудовой потенциал, государственно-частное партнерство, образование, инновации. 